\title{
Pericentriolar Material 1 Protein
}

National Cancer Institute

\section{Source}

National Cancer Institute. Pericentriolar Material 1 Protein. NCI Thesaurus. Code C97902.

Pericentriolar material 1 protein $(2024 \mathrm{aa}, \sim 229 \mathrm{kDa}$ ) is encoded by the human PCM1 gene. This protein is involved in the formation of the centrosome. 